\title{
ПРИРОДНЫЕ ОПАСНОСТИ НА УЧАСТКЕ МАГИСТРАЛЬНОГО ВОДОВОДА В ЦЕНТРАЛЬНОЙ ЯКУТИИ, ВЫЗВАННЫЕ ТЕХНОГЕННОЙ ТЕРМОЭРОЗИЕЙ И ТЕРМОКАРСТОМ
}

\author{
Сальва Андрей Михайлович, \\ ysaa.ykt@gmail.com \\ Якутская государственная сельскохозяйственная академия, \\ Россия, 677007, г. Якутск, ш. Сергеляхское 3 км, 3.
}

\begin{abstract}
Актуальность. Проблемы территорий криолитозоны связаны с широким развитием и активностью распространения процессов термоэрозии, термокарста и других криогенных процессов. На одном из участков трассы магистрального водовода «Лена-Мюрю» в Центральной Якутии возникли опасности, оказывающие негативное воздействие на устойчивость трубопровода. Техногенные криогенные процессы (термокарст, термоэрозия и др.) по масштабам и последствиям приносят магистральному водоводу и обслуживающей автодороге огромный материальный и экономический ущерб. Почему техногенные? Потому, что основной фактор - техногенный - срезка поверхностного слоя землеройной техникой.

Цель: выявление и раскрытие причин природных опасностей криогенных процессов (термокарст и термоэрозия) на трассе магистрального водовода.

Объектом исследования является геокриологическая среда, рассматриваемая при эксплуатации участка магистрального водовода «Сырдах-Борогонцы» в Центральной Якутии.

Методы: полевые маршрутные наблюдения, простые эмпирические исследования (наблюдение, описание, измерение) и некоторые виды инженерно-геологических изысканий. Изучение архивных материалов и новейших сведений позволили проследить развитие криогенных процессов в динамике.

Результаты. При выявлении и раскрытии причин термоэрозии на трассе магистрального водовода были установлены факторы образования термоэрозии и составлена ее картосхема. Выявлены и охарактеризованы места с природными опасностями от влияния криогенных процессов. Геокриологические условия территории благоприятны для развития термокарста и термоэрозии, но ключевым фактором является техногенный - подрезка почвенно-растительного слоя, наличие ледового комплекса, включая верхнечетвертичные отложения супесей и пылеватых песков, а также обводнение термокарстовых котловин.
\end{abstract}

\section{Ключевые слова:}

Природные опасности, многолетнемерзлые породы, ледовый комплекс, криогенные процессы, термокарст, термоэрозия, повторно-жильный лед, магистральный водовод "Лена-Мюрю», Центральная Якутия.

\section{Введение}

В период проектирования, строительства и эксплуатации линейных гидротехнических сооружений очень важно учитывать сложности инженерно-геокриологических условий территории со сложными мерзлотными процессами (термокарста, термоэрозии и других процессов). Они могут быть причинами природных опасностей [1-3]. 0сновные требования к установлению причин и оценке природной опасности такие же, как и у инженерно-геологических изысканий, - это достоверность, достаточность, правильная интерпретация результатов с учетом природных условий и техногенных воздействий. В будущем неучитывание проявлений криогенных процессов может быть очень серьезным: от незначительных признаков - заболачивание территории и развития полигонального микрорельефа (рис. 5), до серьезных ситуаций (рис. 2).

При строительстве и эксплуатации объектов магистрального водоснабжения в Центральной Якутии основными криогенными процессами, которые могут представлять большую опасность и причинить ущерб сооружению, являются: термокарст, термоэрозия, бугры пучения и развитие ледового комплекса, в виде повторно-жильных льдов [4-21]. Одним из способов решения этой проблемы является установление опасных мест активизации термокарстовых и термоэрозионных процессов на основе полевых наблюдений (сбора материалов за весь период) - натурного мониторинга.

Термоэрозия [12] по основному фактору образования очень похожа на такие геологические процессы, как эрозии и оврагообразования, тем, что она провоцируется текучими водами. Что касается оврага, то здесь налицо и сходство морфологических параметров. По аналогии с описанием оврагов автор решил использовать те же параметры для морфологической характеристики термоэрозии.

Цель работы - выявить природные опасности на участках магистрального водовода и провести оценку техногенной термоэрозии для предупреждения опасных ситуаций, связанных с развитием термокарска и термоэрозии.

Изучение основано на материалах полевых инженерно-геологических исследований автора, а также литературных и фондовых данных.

\section{Объект исследования и его особенности}

В качестве объекта исследования был выбран участок эксплуатируемого водовода «Сырдах-Борогонцы» в Центральной Якутии, протяженностью около 16 км (рис. 1). Этот участок принадлежит к магистральному водоводу «Лена-Мюрю», расположенному в Усть-Алданском улусе (районе) Республики Саха (Якутии), находиться на ЛеноАмгинском междуречье, имеет длину более 73 км 
и приурочен к юго-восточной части ЦентральноЯкутской низменности. Магистральный водовод введен в эксплуатацию 30 октября 1998 г. [7]. Трасса водовода проходит по четырем основным террасам: Якутской, Бестяхской, Тюнгюлюнской и Абалахской. Мощность криолитозоны в данном районе составляет от 300 до 500 м. В геологическом строении района принимают участие юрские и неогеновые отложения, которые перекрыты толщей четвертичных отложений. Они представлены, как описано выше, аккумулятивными террасами. Выделяются низкие террасы - Якутская (абсолютная высота 99-102 м), средневысотные - Бестяхская (140-163 м), Тюнгюлюнская псевдотерраса (156-183 м) и Абалахская (201-219 м). Особенностью верхнего горизонта отложений, представленных лессовидными суглинками, супесями [9], реже пылеватыми песками, является развитие ледового комплекса (мощностью 40-60 м). Повторножильные льды полностью пронизывают толщу горных пород [10].

\section{Методы исследования}

Материалы исследования получены в ходе мониторинговых обследований деформаций участка магистрального водовода. Для выявления и раскрытия причин природно-техногенных опасностей криогенных процессов (термокарст, термоэрозия и др.) на трассе магистрального водовода было использовано полевое маршрутное наблюдение, описан и измерен процесс термоэрозии, некоторые виды инженерно-геологических изысканий - бурение скважин и лабораторные исследования грунтов, а также логический анализ. Изучение ар- хивных материалов позволило проследить развитие криогенных процессов в динамике.

\section{Результаты и их обсуждение}

Трасса магистрального водовода «Лена-Мюрю» проложена по территории с активным протеканием термокарстовых и термоэрозионных процессов. Участок водовода «Сырдах-Борогонцы» входит в зону наибольшей активизации криогенных процессов, его протяженность составляет около 16 км. За период наблюдений в 2018 г. на участке «Сырдах-Борогонцы» было обнаружено три проявления термокарсто-термоэрозионной опасности, вызванной техногенной деятельностью человека. По мнению автора, основными факторами этого процесса являются не только снятие в 1996 г. почвенно-растительного слоя во время строительства обслуживающей автодороги, но и последующее образование избыточной влаги и термокарстовых озер.

Первое проявление (рис. 2, фото 1) - это термоэрозионный овраг, образовавшийся в 2011 г. Он находится в 1,4 км по трассе водовода от склона аласа Мюрю. Второе проявление (рис. 2, фото 2) это термокарстовый провал, образованный в 2014 г., который находится в 4 км по трассе водовода от склона аласа. И третье проявление (рис. 2) - собственно термоэрозия, в статье автор более подробно уделяет внимание этому явлению.

Термоэрозия на участке $(6,5$ км) водовода активизировалась весной 2018 г. За лето на этом участке трассы магистрального водовода «Лена-Мюрю» (рис. 3) она прошла поперек обслуживающей дороги и небольшого лесного массива. По мнению авто-

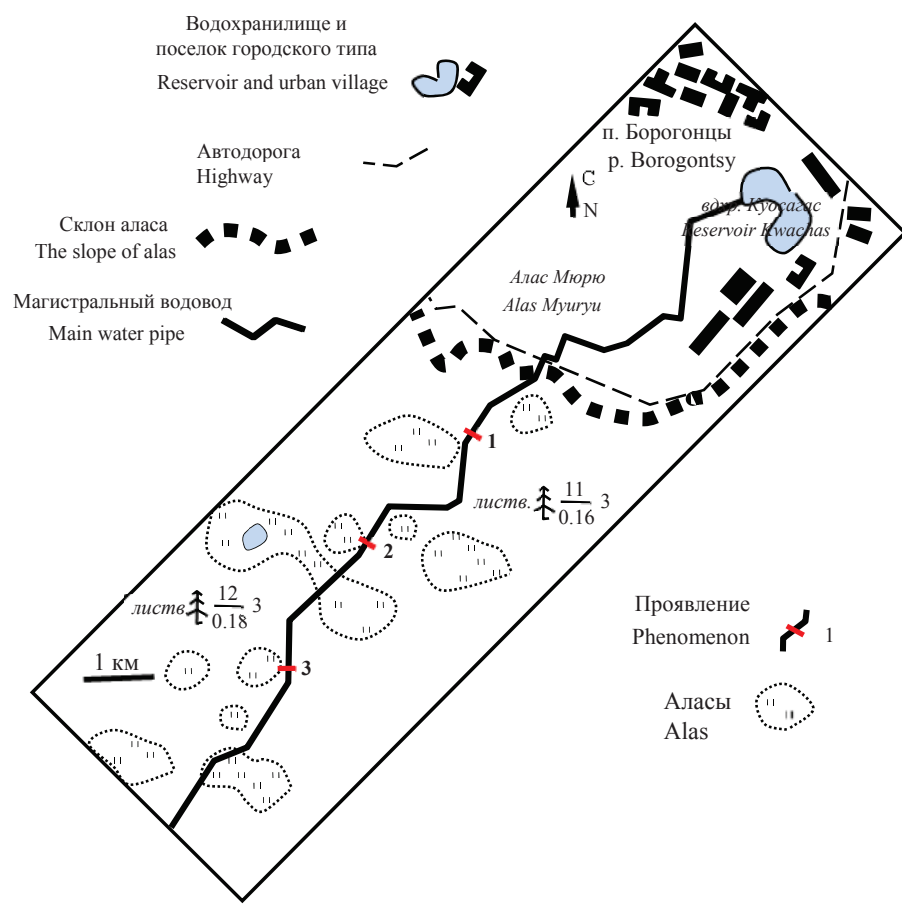

Pис. 1. Картосхема участка магистрального водовода «Сырдах-Борогонцы» с тремя проявлениями криогенных процессов

Fig. 1. Map chart of the area of the main water pipeline «Syrdakh-Borogontsy» with three manifestations of cryogenic processes 

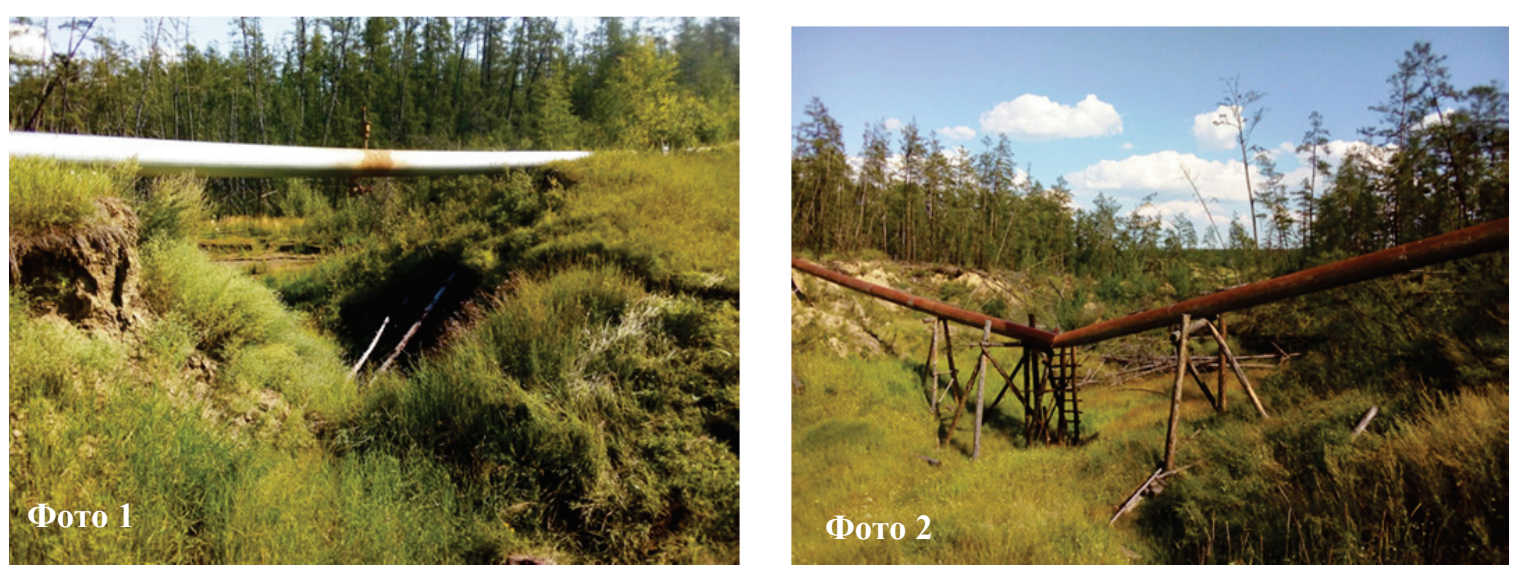

Pис. 2. Места и проявления на участке водовода «Сырдах-Борогонцы», угрожающие прогибом и конкретным механическим разломом: первое проявление (фото 1) - термоэрозионный овраг, второе проявление (фото 2) - термокарстоый провал

Fig. 2. Places and phenomena on the part of the conduit «Syrdakh-Borogontsy», threatening a deflection and a specific mechanical fault: the first manifestation (photo 1) is thermoerosion ravine, the second manifestation (photo 2) is thermokarst failure

ра, причинами появления термоэрозионного процесса являются: удаление бульдозером в 1993 г. почвенно-растительного слоя и вследствие этого возникновение процесса заболачивания территории - образование полигонального микрорельефа - так называемого «былара» и «дюёдя» - стадий развития термокарста (по П.А. Соловьеву [11]).

Проявление техногеной термоэрозии располагается в западном направлении от ее вершины. Устье выходит на алас, ее длина более 200 м, ширина термоэрозии - 8-25 м. Глубина термоэрозии 6-10 м, профиль имеет V-образную форму, на склонах просматриваются клинья повторно-жильных льдов. К данному горизонту отнесены отложения Бестяхской, Тюнгюлюнской и Абалахской террасы, представленные суглинками, супесями, песками пылеватыми. На рис. 3 также показаны места проходки выработок - трех скважин. Бурение осуществлялось ручным способом до $3 \mathrm{~m}$ (рис. 4). Отбор проб проводился в интервале глубин $1 ; 1,5 ; 2$ и 3 м. Клинья повторно-жильных льдов были обнаружены с глубины оттаивания (1,3-1,5 м). Разновидности грунтов определены в лабораторных условиях, которые показали, что это были супеси и пылеватые пески [22].

\section{Заключение}

Развитие и активизация термокарсто-термоэрозионных процессов на участке магистрального водовода «Сырдах-Борогонцы» зависит от сочета-

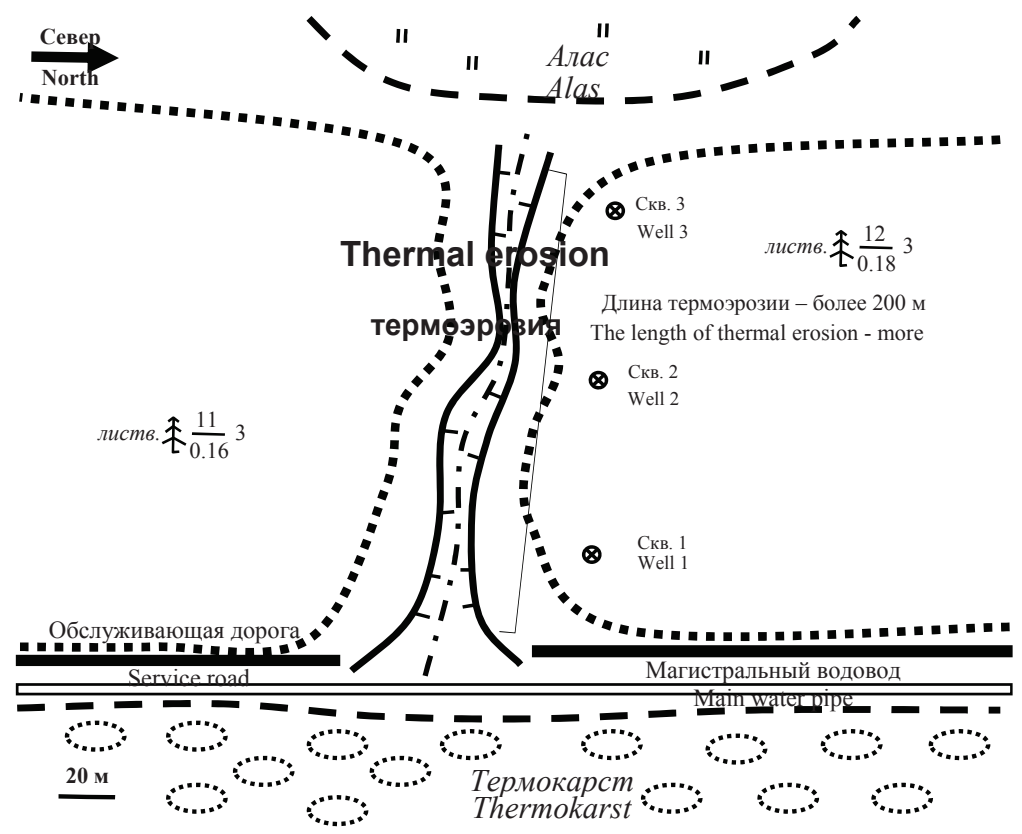

Pис. 3. Плановое положение техногенной термоэрозии на участке водовода «Сырдах-Борогониы»

Fig. 3. Position of technogenic thermal erosion on the site of the water main «Syrdakh-Borogontsy» 


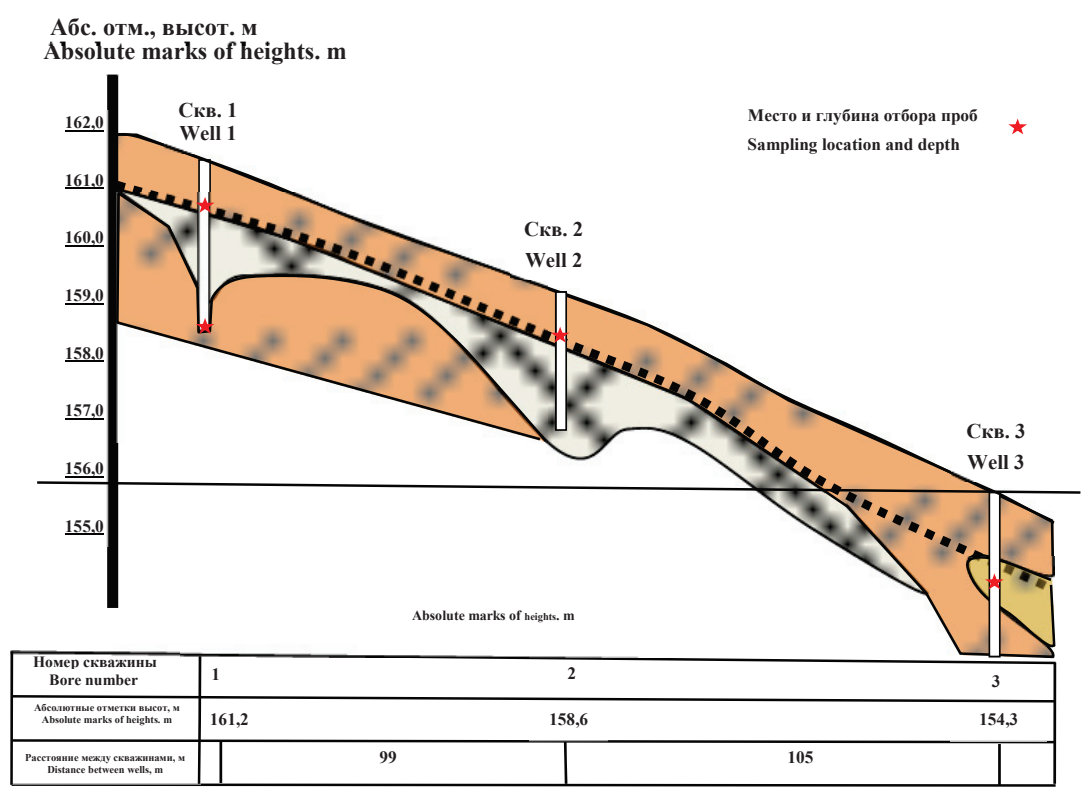

Pис. 4. Инженерно-геологический разрез участка техногенной термоэрозии

Rig. 4. Engineering-geological section of the site of technogenic thermal erosion

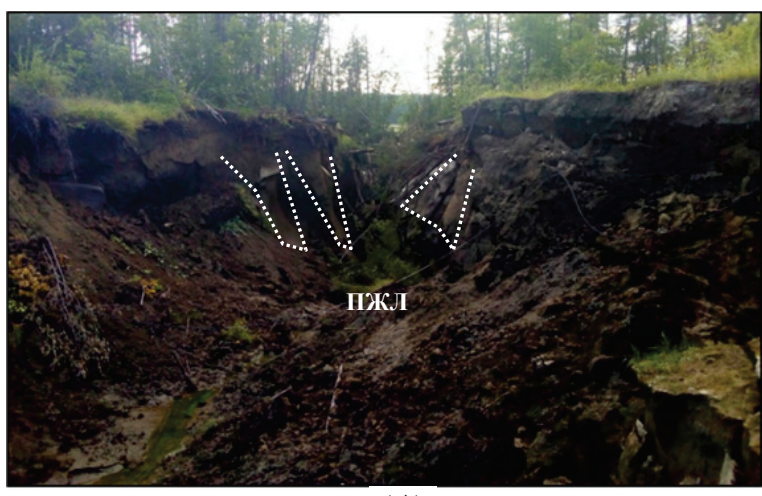

$\mathbf{A} / \mathbf{A}$

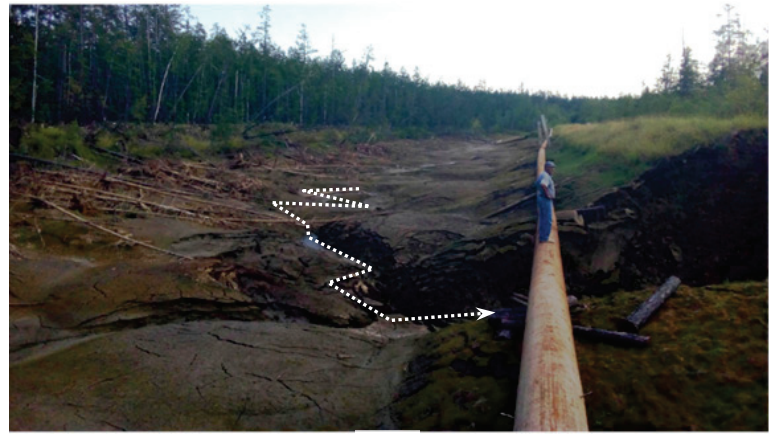

Б/B

Pис. 5. Участок магистрального водовода «Сырдах-Борогониы» и угрожающая ему техногенная термоэрозия: (А) термоэрозия с обнажившимися клиньями повторно-жильных льдов (ПЖЛ), сильнольдистых супесей и песков пылеватых; Б) образование полигонального микрорельефа - так называемого «былара» начальной стадии термокарста и направление исходящего водного потока

Fig. 5. Section of the main conduit «Syrdakh-Borogontsy» and threatening man-made thermal erosion: A) thermal erosion with the exposed wedges to underground (massive) ice, icy sandy loams and silty sands; B) formation of polygonal microrelief - the so-called «bylar» of the initial stage of thermokarst and direction of the outgoing water stream

ния его геокриологических условий, рельефа, режима осадков и, главное, от антропогенной нагрузки. В результате проведенных исследований можно сделать следующие выводы:

1) участок трассы эксплуатируемого водовода находится в зоне сплошного распространения многолетнемерзлых пород и широким развитием криогенных геологических процессов. Он расположен на абсолютной высоте 160-165 м, с аласами до 130-140 м по дну;

2) из основных криогенных геологических процессов на территории прохождения трассы во- довода распространены: термокарст, термоэрозия и заболачивание;

3) проведенные исследования показали, что термоэрозия за один 2018 г. прорезала ледовый комплекс отложений - это невероятно, но факт. По своду правил [3] весьма опасная овражная термоэрозия за час может пройти более $0,1 \mathrm{M}^{2 \text { или }}{ }^{3}$. Получается, в сутки это более 2 м. Это говорит о катастрофической разрушающей активизации термоэрозии, тем более она имеет техногенный характер. 


\section{СПИСОК ЛИТЕРАТУРЫ}

1. ГОСТ 22.0.03-97 Безопасность в чрезвычайных ситуациях. Природные чрезвычайные ситуации. Термины и определения. - М: Стандарт РФ, 2002. - 11 с.

2. ГОСТ Р 22.1.11-2002 Безопасность в чрезвычайных ситуациях. Мониторинг состояния водоподпорных гидротехнических сооружений (плотин) и прогнозирование возможных последствий гидродинамических аварий на них. Общие требования. - М.: Госстандарт России, 2002. - 15 с.

3. СП 115.13330.2016 Геофизика опасных природных воздействий. Актуализированная редакция СНиП 22-01-95. - М.: Минстрой России, 2016. - 49 с.

4. Веремеева А.А. Формирование и современная динамика озерно-термокарстового рельефа тундровой зоны Колымской низменности по данным космической съемки: дис.... канд. геогр. наук. - М., 2017. - 134 с.

5. Макарычева Е.М. Региональный анализ распространения термокарстовых явлений в окрестности магистральной нефтепроводной системы: дис.... канд. геол.-минерал. наук. - М., 2018. - 205 c.

6. Родионова Т.В. Исследование динамики термокарстовых озер в различных районах криолитозоны России по космическим снимкам: дис.... канд. геогр. наук. - М., 2014. - 196 с.

7. Сальва А.М. Магистральный водовод «Лена-Мюрю» в Центральной Якутии // Гидротехническое строительство. 2016. - № 1. - С. 18-20.

8. Сальва А.М. Техноприродные криогенные процессы в зоне влияния магистрального водоснабжения в Центральной Якутии (на примере участка самотечного канала): дис. ... канд. геол.-минерал. наук. - Якутск, 2012. - 136 с.

9. Сальва А.М. Перспективы развития магистрального водоснабжения в заречных районах Центральной Якутии // Водоснабжение и санитарная техника. - 2016. - № 3. - С. 36-40.

10. Сальва А.М. Физические свойства мерзлых грунтов трассы магистрального канала Туора Кюель - Татта в Центральной Якутии // Инженерная геология. - 2013. - № 5. - С. 48-51.

11. Соловьев П.А. Аласный рельеф Центральной Якутии и его происхождение // Многолетнемерзлые породы и сопутствующие им явления на территории Якутской АССР. - М.: Изд-во АН CCCP, 1962. - C. 38-53.
12. Термоэрозия дисперсных пород / под ред. Э.Д. Ершова. - М.: Изд-во Моск. Ун-та. 1982. - 196 с.

13. Шур Ю.Л. Термокарст - к теплофизическим основам учения 0 закономерностях развития процесса. - М.: Недра, 1977. - 80 с.

14. Linkages between lake shrinkage/expansion and sublacustrine permafrost distribution determined from remote sensing of interior Alaska, USA / S.M. Jepsen, C.I. Voss, M.A. Walvoord, B.J. Minsley, J. Rover // Geophys. Res. Lett. - 2013. - P. 40.

15. Ponding vs. baydzherakh formation on Yedoma uplands: Implications for modern thermokarst development and thaw subsidence in North Yakutia / F. Günther, G. Grosse, A. Veremeeva, G. Maximov // XI International Conference on Permafrost. Book of Abstracts / Eds. F. G?nther, A. Morgenstern. - Potsdam, Germany: Bibliothek Wissenschaftspark Albert Einstein, 2016. P. 869-870.

16. Grosse G., Jones B., Arp C. Thermokarst lakes, drainage and drained basins // Treatise on Geomorphology / Ed. by J.F. Shroder. - San-Diego: Academic Press, 2013. - V. 8. - P. 325-353.

17. Satellite-derived changes in the permafrost landscapes of Central Yakutia, 2000-2011: wetting, drying, and fires / J. Boike, T. Grau, B. Heim, F. Günther et al. // Global Planet. Change. 2016. - V. 139. - P. 116-127.

18. Burn C.R., Smith M.W. Development of thermokarst lakes during the Holocene at sites near Mayo, Yukon Territory // Permafrost and Periglacial Processes. - 1990. - V. 1. - P. 161-176.

19. Observing Muostakh Island disappear: erosion of a ground-icerich coast in response to summer warming and sea ice reduction on the East Siberian shelf / F. Günther, P. Overduin, A. Baranskaya, T. Opel, M.N. Grigoriev // The Cryosphere Discussions. 2013. - № 7. - P. 4101-4176.

20. Seasonal thaw settlement at drained thermokarst lake basins, Arctic Alaska / L. Liu, K. Schaefer, A. Gusmeroli, G. Grosse, B.M. Jones, T. Zhang, A.D. Parsekian, H.A. Zebker // The Cryosphere Discuss. - 2013. - № 7. - P. 5793-5822.

21. Murton J.B. Thermokarst sediments and sedimentary structures, Tuktoyaktuk Coastlands, western Arctic Canada // Global and Planetary Change. - 2001. - № 28. - P. 175-192.

22. ГОСТ 25100-2011 Грунты. Классификация. - М.: МНТКС, 2013. -63 c.

Поступила: 18.01.2019 2.

\section{Информация об авторах}

Сальва A.M., кандидат геолого-минералогических наук, доцент кафедры землеустройства и ландшафтной архитектуры Якутской государственной сельскохозяйственной академии. 


\title{
NATURAL HAZARDS AT THE SITE OF THE WATER MAIN IN CENTRAL YAKUTIA, CAUSED BY ANTHROPOGENIC THERMOEROSIVE AND THERMOKARST
}

\author{
Andrey M. Salva, \\ salvaam@mail.ru \\ Yakutsk State Agricultural Academy, \\ 3, Sergelyakhskoe highway 3 km, Yakutsk, 677007, Russia.
}

The relevance. The problems of the cryolithozone territories are related to the wide development and activity of thermal erosion, thermokarst and other cryogenic processes. On one of the sections of the route of the water main "Lena-Myuryu» in Central Yakutia the danger occurs. It has negative impact on stability of the pipeline. Man-made cryogenic processes (thermokarst, thermal erosion, etc.) on the scale and consequences bring great material and economic damage to the main water pipeline and road maintenance. Why anthropogenic? Because the main factor - technogenic-cutting of the surface layer by earthmoving machinery.

The main aim of the research is to identify and disclose the causes of natural hazards of cryogenic processes (thermokarst and thermal erosion) on the route of the main water pipeline.

The object of the study is the geocryological environment considered in operation of the section of the main water conduit "Syrdah-Borogontsy» in Central Yakutia.

Methods: field route observations, simple empirical studies (observation, description, measurement) and some types of engineeringgeological surveys. The study of archival materials and the latest information allowed tracing the development of cryogenic processes in dynamics.

Results. At detection and disclosure of the reasons of thermal erosion on the route of the water main the factors of its formation were determined and its map chart was made. The author has identified and characterized the places with natural hazards from the influence of cryogenic processes. The geocryological conditions of the territory are favorable for development of thermokarst and thermal erosion, but the key factor is technogenic-pruning of the soil and vegetation layer, the presence of the ice complex, including the upper Quaternary deposits of sandy loams and silty sands, as well as the flooding of thermokarst basins.

\section{Key word:}

Natural hazards, permafrost, ice complex, cryogenic processes, thermokarst, thermoerosion, underground (massive) ice, trunk main "Lena-Myuryu», Central Yakutia.

\section{REFERENCES}

1. GOST 22.0.03-97 Bezopasnost $v$ chrezuychaynykh situatsiyakh Prirodnye chrezvychaynye situatsii. Terminy i opredeleniya [Safety in emergencies. Natural emergencies. Terms and definitions] Moscow, Standard of Russian Federation, 2002. 11 p.

2. GOST R 22.1.11-2002 Bezopasnost v chrezvychaynyh situatsiyakh. Monitoring sostoyaniya vodoprovodnykh gidrotekhniches kokh ssoruzheny (plotin) i prognozirovznie vozmozhnykh posledstoy gidrodinamicheskikh avary na nikh. Obshchie trebovaniya [Safety in emergencies. Monitoring the state of water-bearing hydraulic structures (dams) and forecasting the possible consequences of hydrodynamic accidents on them. General requirements]. Moscow, State Standard Of Russia, 2002. 15 p.

3. SP 115.13330.2016 Geofizika opasnykh prirodnykh vozdeystviy [Geophysics of natural hazards]. Actualized edition of SNiP 22-01-95. Moscow, Minstroy Rossii Publ., 2016. 49 p.

4. Veremeeva A.A. Formirovanie i souremennaya dinamika ozerno termokarstovogo relefa tundrovoy zony Kolymskoy nizmennosti po dannym kosmicheskoy semki. Dis. Kand. nauk [Formation of the modern dynamics of the lake-thermokarst relief of the tundra zone of the Kolyma lowland according to the space survey. Cand. Diss.] Moscow, 2017. 134 p.

5. Makarycheva E.M. Regionalny analiz rasprostraneniya termokarstovykh yavleniy v okrestnosti magistralnoy nefteprovodnoy siste$m y$. Dis. Kand. nauk [Regional analysis of propagation of thermokarst phenomena in the vicinity of the main oil pipeline system. Cand. Diss.] Moscow, 2018. 205 p.

6. Rodionova T.V. Issledovanie dinamiki termokarstovykh ozer $v$ razlichnykh rayonakh kriolitozony Rossii po kosmicheskim snimkam. Dis. Kand. nauk [Study of thermokarst lakes dynamics in different regions of the cryolithozone of Russia by space images. Cand. Diss.]. Moscow, 2014. 196 p.
7. Salva A.M. Trunk main Lena-Muru in Central Yakutia. Hydrotechnical construction, 2016. no 1, pp. 18-20. In Rus.

8. Salva A.M. Tekhnoprirodnye kriogennye protsessy v zone vliyaniya magistralnogo vodosnabzheniya $v$ Tsentralnoy Yakutii (na primere uchastka samotechnogo kanala). Dis. Kand. nauk [Technopriodic processes in the zone of influence of the main water supply in Central Yakutia (on the example of the section of the gravity channel). Cand. Diss.]. Yakutsk, 2012.136 p.

9. Salva A.M. Prospects of development of main water supply in the Central Yakutia river regions. Water Supply and sanitary engineering, 2016, no. 3, pp. 36-40. In Rus.

10. Salva A.M. Physical properties of frozen soils of the trunk channel Tuora Kuel - Tatta in Central Yakutia. Engineering Geology, 2013, no. 5, pp. 48-51. In Rus.

11. Soloviev P.A. Alasny relief Tsentralnoy Yakutii i ego proiskhozhdenie [Alasny relief of Central Yakutia and its origin]. Mnogoletnemerzlye porody $i$ soputstvuyushchie im yavleniya na territorii yakutskoy ASSR [Permafrost and associated phenomena in the Yakut ASSR]. Moscow, USSR AS Press, 1962. pp. 38-53.

12. Ershov E.D. Termoeroziya dispersnykh porod [Thermal erosion of dispersed rocks]. Moscow, Moscow University Publ., 1982. 196 p.

13. Shur Yu.L. Termokarst: $k$ teplofizicheskim osnovam ucheniya 0 zakonomernostyakh razvitiya protsessa [Thermokarst: thermophysical fundamentals of the doctrine of the regularities in process development]. Moscow, Nedra Publ., 1977. 80 p.

14. Jepsen S.M., Voss C.I., Walvoord M.A., Minsley B.J., Rover J. Linkages between lake shrinkage/expansion and sublacustrine permafrost distribution determined from remote sensing of interior Alaska, USA. Geophys. Res. Lett., 2013, pp. 40.

15. Günther F., Grosse G., Veremeeva A., Maximov G. Ponding vs. baydzherakh formation on Yedoma uplands: Implications for modern thermokarst development and thaw subsidence in North Yakutia. XI International Conference on Permafrost. Book of Ab- 
stracts. Eds. F. Günther, A. Morgenstern. Potsdam, Germany, Bibliothek Wissenschaftspark Albert Einstein, 2016. pp. 869-870.

16. Grosse G., Jones B., Arp C. Thermokarst lakes, drainage and drained basins. Treatise on Geomorphology. Ed. by J.F. Shroder. SanDiego, Academic Press, 2013. Vol. 8, pp. 325-353.

17. Boike J., Grau T., Heim B., G?nther F. Satellite-derived changes in the permafrost landscapes of Central Yakutia, 2000-2011: wetting, drying, and fires. Global Planet. Change, 2016, vol. 139, pp. 116-127.

18. Burn C.R., Smith M.W. Development of Thermokarst lakes during the Holocene at sites near Mayo, Yukon Territory. Permafrost and Periglacial Processes, 1990, vol. 1, pp. 161-176.

19. Günther F., Overduin P., Baranskaya A., Opel T., Grigoriev M.N. Observing Muostakh Island disappear: erosion of a ground-icerich coast in response to summer warming and sea ice reduction on the East Siberian shelf. The Cryosphere Discussions, 2013, no. 7, pp. 4101-4176.

20. Liu L., Schaefer K., Gusmeroli A., Grosse G., Jones B.M., Zhang T., Parsekian A.D., Zebker H.A. Seasonal thaw settlement at drained thermokarst lake basins, Arctic Alaska. The Cryosphere Discuss, 2013, no. 7, pp. 5793-5822.

21. Murton J.B. Thermokarst sediments and sedimentary structures, Tuktoyaktuk Coastlands, western Arctic Canada. Global and Planetary Change, 2001, no. 28, pp. 175-192.

22. GOST 25100-2011. Grunty. Klassifikatsiya [State Standard 25100-2011. Soils. Classification]. Moscow, MNTKS Publ., $2013.63 \mathrm{p}$.

Received: 18 January 2019.

\section{Information about the authors}

Andrey M. Salva, Cand. Sc., associate professor, Yakutsk State Agricultural Academy. 